DOI: $10.14451 / 1.177 .40$

\title{
ТРАНСФОРМАЦИЯ ИНСТРУМЕНТОВ ОБЕСПЕЧЕНИЯ УСТОЙЧИВОГО РАЗВИТИЯ УРАНОДОБЫВАЮЩЕЙ ОТРАСЛИ
}

\author{
(c) 2019 Мясоедов Сергей Александрович \\ доктор экономических наук, доцент \\ Академия маркетинга и социально-информационных технологий (ИМСИТ), Россия, Краснодар \\ E-mail:myasoedov8@mail.ru
}

Одним из факторов риска любой экономической системы является наличие возможности потери устойчивости системы в целом; обеспечение устойчивого развития отраслей экономики сопряжено прежде всего с оперативностью реагирования на изменяющиеся условия развития, институциональные основы, ценовые колебания; до не давнего времени уранодобывающая отрасль находилась под жёстким воздействием ценовой конъюнктуры, сформировавшейся после аварий на ядерных объектах в Японии; рынок ураносодержащих материалов считается высокотехнологичным и высокодоходным, при этом наибольшую норму рентабельности имеют продукты последних стадий технологического передела уранового сырья и воздействие на компании, добывающие уран, неизбежно сказывается на все экономические показатели организаций включённых в технологическую цепочку производства продуктов, содержащих урановое сырьё.

Ключевые слова: экономика уранодобывающей промышленности, устойчивое развитие уранодобывающей промышленности, инструменты обеспечения устойчивости развития добывающих отраслей

Урановое сырьё относится к энергетическому сырью, которое помимо военного использования применяется для выработки электроэнергии, так же, как и уголь, нефть, газ.

Низкообогащённый уран используется как сырьевая основа для создания топлива реакторов АЭС.

На рынке по степени обогащения выделяют следующие виды урана:

- мало обогащённый уран (обеднённый (содержание по U-235 0,2-0,3\%), природный $(0,72 \%))$

- низкообогащённый (концентрация U-235 ниже 20\%) или обогащённый уран для АЭС (в зависимости от типа реактора 3-4\%, 3-8\%, максимум для исследовательских реакторов обогащение 13-19\%)

- оружейный уран или высокообогащённый уран (при обогащении 20-90\%), пригодный к оружейному использованию, а так же в реакторах атомных подводных лодок (АПЛ).

Основным товарным продуктом уранодобывающей промышленности считается закисьокись урана (U3O8).

Жёлтый кек является основой для получения (после аффинажа) путём конверсии тетрафторида урана UF4, а затем и гексафторида урана (UF6) (ГФУ).

Следующим пунктом в технологической цепочке является процесс обогащения урана. Технология фабрикации (производства) ядерного топлива для АЭС, включает в том числе получение таблеток из UO2, которые используются в производстве ТВЭЛов и ТВС (тепловыделяющая сборка).

И завершающей стадией высокотехнологичной цепочки производства ураносодержащих продуктов, основой которой является уранодобывающая промышленность, является строительство АЭС.

Только небольшое число государств мира обладают технологиями по получению обогащённого урана: Аргентина, Бразилия, Великобритания, Германия, Израиль, Индия, Иран, Китай, Нидерланды, Пакистан, Россия, Северная Корея, США, Франция, Япония.

По ряду источников, главный производитель урана в мире, Казахстан, активно работал по получению от Cameco Corporation и Areva технологий конверсии окиси-закиси урана в гексафто- 
рид урана, также Украина и Южная Корея имеют потенциал получения технологий обогащения урана.

Однозначным лидером в мире по имеющимся в наличии мощностям обогащения урана выступает Российская Федерация.

Наша страна одно из немногих государств мира, которое владеет всеми технологиями:

- технологии добычи - Якутия, Забайкальский край, Курганская область, Республика Бурятия и в других регионах;

- технологии конверсии - г. Северск (ОАО «Сибирский химический комбинат»), Ангарск (ОАО «Ангарский электролизный химический комбинат») и Глазов (ОАО «Чепецкий механический завод») и другие организации;

- технологии обогащения - Новоуральск (Свердловск-44), Зеленогорск (Красноярск-45), Северск (Томск-7), Ангарск и другие объекты;

- технологии по производству высокообогащённого урана и плутония - Уральский электрохимический комбинат (УЭХК) (Новоуральск, Свердловская область), ФГУП ПО «Электрохимический завод» (Зеленогорск, Красноярский край), Сибирский химический комбинат (СХК) (Северск, Томская область), Ангарский электрохимический комбинат (Ангарск, Иркутская область). Озерск (Челябинск - 65, ПО «Маяк»), Железногорск (Красноярск - 26), реакторы АЭС и другие объекты;

- технологии фабрикации топлива, производства ТВЭЛов - ОАО «Машиностроительный завод» (Электросталь, Московская обл.), ОАО «Новосибирский завод химконцентратов» (Новосибирск, Новосибирская обл.) и ОАО «Чепецкий механический завод» (Глазов, Удмуртия).

Самым технологически простым считается процесс извлечения ураносодержащей породы, урана из недр, но в структуре себестоимости производства ТВЭЛов затраты на сырьё составляют одну треть (30-40\%) в себестоимости конечного продукта.

Добычей урана занимаются организации специализацией которых является добыча ураносодержащей породы, также уран добывают попутно при разработке месторождений других полезных ископаемых, например, угля, золота и т.п.

Уран добывают с целью:
- его последующей реализации,

- для собственного производства ураносодержащей продукции более высокой степени передела (производство гексафторида урана UF6; обогащённого урана, производство из UO2 порошка, таблеток);

- производства ТВЭЛов и ТВС.

Поэтому степень влияния, чувствительности на колебания мировой цены различны: прямая зависимость цена и объёмы добычи для производителей урана, которые добывают его только для продажи на рынке и менее чувствительная зависимость для производителей, входящих в холдинги вертикально интегрированных промышленных групп. Интегрированные производители поставляют сырьё, как правило, для изготовления ядреного топлива АЭС, и ценовые колебания на сырьё перекрываются высокой нормой рентабельности при производстве топливных таблеток или ТВЭЛов.

Ведущими мировыми компаниями по добыче урана являются Kazatomprom (Казахстан, «Казатомпром»), Саmесо Corporation (Канада), Orano (Areva, Франция), Uranium One Inc. (Россия, «Росатом»), CNNC\&CGN (Китай, China National Nuclear Corporation).

По объёму добычи урана доминируют Казахстан (более 40\%), Канада, Австралия.

В мире наблюдается превышение предложения оксида урана над его мировым спросом, в том числе за счёт вывода большего количества ядерных реакторов из эксплуатации в сравнении с величиной планируемых к вводу и строительству.

Кроме этого, развитие уранодобывающей отрасли сдерживают низкие мировые цены на оксид урана, которые с 73 долларов США за фунт по спотовым поставкам 2010-02.2011 год (рекорд 138 долларов за фунт в июне 2007 года.) снизились максимум до 17,5 долл/фунт в феврале 2017 года.

Причиной такого резкого снижения цены на оксид урана стала авария в Японии на АЭС Фукусима - 1 и последовавший мировой общественный резонанс о высоком уровне опасности ядерной энергетики для среды обитания человечества.

Семилетняя динамика снижения цены на оксид урана привела к снижению мощностей 
уранодобывающих организаций; к консервации месторождений, рудников; а в 2018 году уже публично крупнейшие производители Kazatomprom, Cameco Corporation объявили о сокращении сотрудников, и Cameco Corporation о снижении объёмов выплат по дивидендам.

В результате уранодобывающие компании мира приводят уровень добычи к потребностям рынка, иными словами, сокращаются объёмы добычи у целого ряда производителей.

Однако, следует учитывать особенности и самой отрасли, связанные с продолжительным временным лагом от момента разведки месторождения до его ввода в эксплуатацию.

Поэтому затяжной ценовой спад на оксид урана уже сейчас формирует предпосылки для резкого взлёта цены на данный продукт по следующим причинам:

1. вввод в эксплуатацию ранее законсервированных объектов будет производится осторожно и только при наличии стабильного тренда роста цен на оксид урана в течении нескольких лет, что в условиях ограничения предложения ведёт к росту цены;

2. освоение новых месторождений в уранодобывающей отрасли сопряжено с огромным количеством согласований, создании мощной инфраструктуры, значительных энергоресурсов - на реализацию всех данных проектов требуется время, что создаёт дополнительные факторы для роста цены, в связи с ограничением предложения;

3. при анализе рынка эксперты отмечают появление компаний, занимающихся скупкой излишков оксида урана, что также ведёт к росту спроса и цены при снижении объёмов добычи в мире. Данный факт может свидетельствовать о прохождении ценового минимума на оксид урана;

4. сохраняется стабильный спрос на уран в качестве сырья для реакторов АЭС. Атомная энергетика является основным источником выработки электричества во Франции, Бельгии и ряде других государств Европы, хотя после аварии на АЭС Фукусима - 1 европейские государства заявляли о сокращении либо об отказе от проектов в атомной энергетике, но по прошествии лет риторика о ядерной опасности атомной энергетики немного поутихла.
По данным МАГАТЭ в структуре себестоимости электроэнергии на атомных станциях более 50\% занимает амортизация, затем стоимость топлива и статья эксплуатационные издержки. При снижении рыночной цены на урановое топливо себестоимость атомной энергии несомненно снижается и атомная энергетика становиться особо привлекательной для инвесторов в сравнении с нефте и газодобычей и с учётом стоимости объёма нефти и газа, который используется европейскими государствами для получения энергии.

По классификации МАГАТЭ выделяют урановые руды при себестоимости добычи до 40, 80, 130 и 260 долл/кг.

Минерально- сырьевая база за последние 20 лет по объёму всех разведанных запасов урана в мире увеличилась, а в структуре запасов величина запасов урана с себестоимостью добычи до 40 долларов США за 1 килограмм не уклонно снижается.

Более половины разведанных запасов урана размещены в Австралии, Казахстане, Канаде, Российской Федерации.

Самые низкие издержки при добыче урановых руд отмечаются на месторождениях Австралии, Канады, до 40 долларов США за 1 кг за счёт более высокого содержания урана в руде.

Добыча урана производится карьерным способом, подземным способом, полезное ископаемое может извлекаться из океанических отложений.

Добыча урана сопряжена с радиационным риском для биологических объектов как в стадии освоения месторождения, так и после выработки месторождения.

Добыча урана считается одним из самых опасных этапов ядерного топливного цикла, по причине получения значительных радиационных доз, количества пострадавших, а также ввиду образования больших объёмов низкоактивных радиоактивных отходов. Отмечается, что добыча урана производится, как правило, с нарушением геологических структур, заводнением и без соизвлечения тория и радия.

Процессу производства гексафторида урана для разделения изотопов сопутствуют выделение фтористоводородной и азотной кислоты, фтора, химических соединений урана в форме 
аэрозолей и водяных растворов.

Обогащение урана сопряжено с утечкой в грунтовые воды радионуклидов и токсичных химических отходов (полихлорированные бифенилы (ПХБ), хлор, аммиак, нитраты, цинк, мышьяк).

Наиболее серьёзной проблемой, рассматриваемой на страницах печати, является сложность утилизации плутония, образующегося при работе ядерного реактора из урана-238. Плутоний-239 считается грязным радионуклидом с периодом полураспада 5440 лет, данное соединение, по мнению специалистов, испытывает быстрые фазовые превращения и распад, контроль за ним, считается практически бесконечным по времени, дорогим и сложным.

Опасным этапом ядерно-топливного цикла является переработка облучённого топлива и выделение плутония (репроцессинг), остекловывание отработанного ядерного топлива. В истории эксплуатации ядерных объектов встречались случаи выброса в атмосферу криптона-85 и углерода-14.

В средствах массовой информации довольно активно обсуждались сложности с хранением накопленных радиоактивных отходов в подземных хранилищах в Горлебене (Германии), известны проблемы с хранением отработанного ядерного топлива в Селлафильде (Великобритания).

Несомненно, ядерная энергетика занимает ведущее место в энергобалансе многих стран, но производство ядерного топлива сопряжено с серьёзными проблемами.

Ядерная энергетика, в условиях низкой цены на оксид урана, поддерживает стабильный спрос на продукцию уранодобывающих организаций, которые активно трансформируют организационные, управленческие инструменты [4] для обеспечения устойчивого развития уранодобывающей отрасли, а именно:

маркетинговые

- отказ от продаж сырья на спотовом рынке;

- отказ от долгосрочных контактов на продажу сырья;

производственные

- приостановка производственных программ, программ развития;

- приостановка геолого-разведочных работ
(ГРР);

- сокращение сотрудников, рабочей силы;

- сокращение добывающих мощностей;

управленческие

- изменение и оптимизация логистики;

- сокращение, объединение функций управленческих подразделений;

- поглощение уранодобывающих компаний более сильными участниками рынка, создание объединений, интегрированных групп;

- значительное сокращение размера дивидендов на акцию.

Ураносодержащими продуктами, аккумулирующими основную часть прибыли в отрасли, считаются топливные таблетки и топливные сборки, поэтому получение технологий по их производству обеспечивают поступлении прибыли в размерах на порядок выше, чем от продажи закиси-окиси урана.

Российская Федерация занимает первое место в мире по мощностям обогащения урана.

По другим высокотехнологичным видам продукции и услуг в сфере ядерной энергетики заметно уступает по объёмам сделок США и Франции:

- по строительству ядерных реакторов (ЯППУ, Ядерная паропроизводящая установка, Nuclear steam supply system, NSSS), по разным данным у Российской Федерации до 15\% рынка, лидер США;

- по рынку утилизации ядерного топлива (не более 5\%, лидер Франция);

- по объёмам поставок ядерного топлива (не более 20\%, лидер США и Франция);

- обслуживание АЭС (до 10\%, лидер США).

Чтобы получить технологии по производству высокотехнологичных ураносодержащих продуктов, ведущие страны по добыче урана, не обладая собственными технологиями, готовы предоставить в разработку на своей территории урановые месторождения, создают совместные предприятия.

Инвестиции в уранодобывающую промышленность таких государств происходят по схемам:

1. активы на активы (используется при отсутствии, недостачи собственных средств у государства или компании),

2. активы и продажа сырья на кредиты (до- 
быча ведётся под конкретного потребителя урановой продукции),

3. активы на политические уступки (допускают компании ведущих государств мира, играющих ключевую роль в мировой политики),

4. активы и кооперация на активы и кооперацию (создание равноправных организаций, партнёрских отношений консорциумов, совместных предприятий),

5. активы на обещание технологий (доступ к высокорентабельным месторождениям на гарантии передачи технологий по получению гексафторида урана, возможно и по обогащению урана при соблюдении договора о не распространении).

\section{Выводы:}

1. основные запасы урана сосредоточены на территории ведущих государств производителей, это Казахстан, Австралия, Канада.

2. рост цен на оксид урана будет стабильным за счёт наличия постоянных потребностей для функционирования АЭС, строительства новых АЭС, сокращения предложений (мощностей добычи у большинства производителей урана).

3. в условиях низких цен на природный уран, продукции добывающих организаций наметился тренд на создание вертикально инте- грированных объединений для производства урановой продукции для всех рынков: оксида урана, гексафторида урана, обогащённого урана, фабрикации урана (топливных таблеток, ТВЭЛ, ТВС), строительство АЭС.

4. конкуренция на рынке остаётся высокой, при производстве высокотехнологичной ураносодержащей продукции государствами лидерами являются США, Франция, Российская Федерация.

5. за последние годы после аварии на АЭС Фукусима-1, уранодобывающие организации в качестве основных инструментов поддержания устойчивого развития отрасли использовали такие как консервация месторождений и мощностей добычи, сокращение численности персонала, отказ от программ развития, создание вертикально интегрированных групп, изменение политики сбыла, сокращение выплат по акциям.

6. нерешённость технических и технологических проблем с отработанными месторождениями, отвалами, с захоронением ядерных отходов наносит серьёзную угрозу среде обитания человечества.

7. риск получения ядерных продуктов и технологий по производству атомного оружия террористическими организациями.

\section{Библиографический список}

1. Мясоедов С.А., Жаровский Д.С. Анализ аспектов экономической политики деятельности хозяйствующих субъектов рынка редкоземельных металлов //Экономические науки.- М. - 2014. № 04.(113). - С.22-25.

2. Мясоедов С.А. Анализ концептуальных основ устойчивого экономического развития//Экономические науки.-М.-2017. № 7(152).- С. 19-22.

3. Мясоедов С.А. Анализ процесса формирования концепции устойчивого развития экономических отношений //Экономические науки.- М. - 2016. № 04.(137) - С.13-17.

4. Мясоедов С.А. Оценка уровня устойчивого экономического развития и экономическая безопасность отраслей минерально-сырьевого комплекса//Экономические науки. - М. - 2018. - № 12(169). - С. 65-69.

5. https://www.orano.group/

6. https://www.iaea.org/

7. https://www.rosatom.ru/production/mining/

8. Cameco, 9 Feb 2017, 'Cameco's (CCJ) CEO Tim Gitzel on Q42016 Results - Earnings Call Transcript', https:// seekingalpha.com/article/4044994-camecos-ccj-ceo-tim-gitzel-q4-2016-results-earnings-call-transcript

9. Steve Kidd, 13 Sept 2017, 'Uranium - what are the dynamics between China and Kazakhstan?', http://www. neimagazine.com/opinion/opinionuranium-what-are-the-dynamics-between-china-and-kazakhstan-5924884/

10. World Nuclear Association, February 2018, 'World Nuclear Power Reactors \& Uranium Requirements', http:// www.world-nuclear.org/information-library/facts-and-figures/world-nuclear-power-reactors-and-uraniumrequireme.aspx 
11. Rhiannon Hoyle and Mayumi Negishi, 31 July 2016, 'Japan Nuclear-Power Jitters Weigh on Global Uranium Market', http://www.wsj.com/articles/japan-nuclear-power-jitters-weigh-on-global-uranium-market-1469990663

12. http://promtu.ru/dobyicha-resursov/dobyicha-urana-v-rossii-i-mire

13. http://www.atomic-energy.ru/news/2017/04/21/75101 